\title{
OPEN
}

\section{Publisher Correction: Prokineticin receptor 2 affects GnRH3 neuron ontogeny but not fertility in zebrafish}

\author{
Ivan Bassi, Francesca Luzzani, Federica Marelli, Valeria Vezzoli, Ludovica Cotellessa, \\ David A. Prober, Luca Persani, Yoav Gothilf \& Marco Bonomi
}

Correction to: Scientific Reports https://doi.org/10.1038/s41598-020-64077-2, published online 06 May 2020

The original version of this Article contained an incorrect title where, "Prokineticin receptor 2 affects GnRH3 neuron ontogeny but not fertility in zebrafish" was incorrectly given as "Knocking-down of the Prokineticin receptor 2 affects reveals its complex role in the regulation of the hypothalamus-pituitary-gonadal axis in the zebrafish model".

This has now been corrected in the PDF and HTML versions of the Article.

(c) (i) Open Access This article is licensed under a Creative Commons Attribution 4.0 International License, which permits use, sharing, adaptation, distribution and reproduction in any medium or format, as long as you give appropriate credit to the original author(s) and the source, provide a link to the Creative Commons license, and indicate if changes were made. The images or other third party material in this article are included in the article's Creative Commons license, unless indicated otherwise in a credit line to the material. If material is not included in the article's Creative Commons license and your intended use is not permitted by statutory regulation or exceeds the permitted use, you will need to obtain permission directly from the copyright holder. To view a copy of this license, visit http://creativecommons.org/licenses/by/4.0/.

(c) The Author(s) 2020 